\title{
PEMODELAN PRODUK DOMESTIK REGIONAL BRUTO (PDRB) DI PROVINSI JAWA TENGAH MENGGUNAKAN BOOTSTRAP AGGREGATING MULTIVARIATE ADAPTIVE REGRESSION SPLINES (BAGGING MARS)
}

\author{
Maryam Jamilah An Hasibuan', Agus Rusgiyono², Diah Safitri ${ }^{3}$ \\ 1,2,3 Departemen Statistika FSM Universitas Diponegoro \\ Email: agus.rusgi@gmail.com
}

\begin{abstract}
Increased economic improvement is one way to improve people's welfare in certain areas. Gross Regional Domestic Product (GRDP) is one of the macroeconomic indicators used to measure economic growth in a region. Related to the economy in Central Java Province increased from year to year. Increasing economic growth is inseparable from the contribution of factors that sufficiently contribute to the GRDP. Factors that are the cause of GRDP are Regional Original Income, Foreign Investment, and Domestic Investment. The method used to model the factors that influence Gross Regional Domestic Product is the Multivariate Adaptive Regression Spline (MARS) method and combine it with Bagging. MARS method is one method that uses nonparametric regression and high dimension data. The best model used is a model with a combination of $\mathrm{BF}=6, \mathrm{MI}=1, \mathrm{MO}=$ 0 with GCV of 5.667,6680. Then bagging is done on the initial data set with $10,25,35,40,55,75$, 85, 90 and 100 bootstrap replications. GCV produced in bagging MARS 2.258,6192. GCV values obtained from MARS bagging are smaller compared to the MARS method. This shows that bagging can reduce the value of GCV and increase accuracy, making this method can be used in this study.
\end{abstract}

Keywords: GRDP, GCV, MARS, Bagging

\section{PENDAHULUAN}

Indonesia merupakan negara yang luas dengan 33 provinsi di dalamnya. Setiap daerah provinsi di Indonesia akan berusaha untuk meningkatkan pertumbuhan ekonominya, termasuk Provinsi Jawa Tengah. Pertumbuhan ekonomi yang meningkat di masing-masing provinsi mengindikasikan bahwa pemerintah mampu meningkatkan kesejahteraan masyarakatnya. Pertumbuhan ekonomi yang tinggi merupakan salah satu indikator untuk menilai keberhasilan pembangunan suatu negara dan menjadi sasaran utama pembangunan bagi negara berkembang.

Pembangunan ekonomi daerah adalah suatu proses dimana pemerintah daerah dan masyarakatnya mengelola sumber daya yang ada dan membentuk suatu pola kemitraan antara pemerintah daerah dan sektor swasta untuk menciptakan suatu lapangan pekerjaan dan merangsang perkembangan kegiatan ekonomi di dalam wilayah tersebut (Arsyad, 1999).

Produk Domestik Bruto (PDB) merupakan salah satu indikator makro ekonomi yang pada umumnya digunakan untuk mengukur kinerja ekonomi di suatu negara. Pada dasarnya, PDB adalah jumlah nilai akhir dari seluruh sektor manufaktur dan jasa, baik atas dasar harga berlaku (PDB nominal) dan atas dasar harga konstan (PDB riil). PDB suatu negara dihitung berdasarkan oleh nilai-nilai Produk Domestik Regional Bruto (PDRB) dari seluruh wilayah di negara tersebut.

PDRB adalah jumlah nilai tambah yang dihasilkan oleh seluruh aktivitas produksi di dalam perekonomian daerah (BPS, 2013). PDRB atas dasar harga konstan dipakai untuk 
dapat mengetahui pertumbuhan ekonomi dari tahun ke tahun atau dengan kata lain pertumbuhan ekonomi setiap tahunnya.

Beberapa faktor yang diduga menyebabkan meningkatnya PDRB yaitu Pendapatan Asli Daerah (PAD), Penanaman Modal Asing (PMA), dan Penanaman Modal Dalam Negeri (PMDN). Dalam peningkatan pertumbuhan penduduk daerah terlihat dari perkembangan pendapatan asli daerah yang positif disisi penerimaannya dan peranannya dari tahun ke tahun. PAD merupakan salah satu sumber penerimaan daerah yang memiliki keterkaitan dengan pertumbuhan ekonomi. Menurut Saragih (2003), daerah yang memiliki pertumbuhan ekonomi positif memiliki kemungkinan kenaikan PAD atau kata lain adanya peningkatan PAD merupakan akses dari pertumbuhan ekonomi dan diantara pertumbuhan ekonomi dan PAD diyakini terdapat korelasi.

Salah satu metode dalam statistik yang dapat digunakan untuk memodelkan faktorfaktor yang mempengaruhi Produk Domestik Regional Bruto adalah dengan menggunakan metode Multivariate Adaptive Regression Spline (MARS). Menurut Friedman (1991), metode Multivariate Adaptive Regression Splines (MARS) merupakan pendekatan untuk regresi nonparametrik. Karena MARS merupakan metode regresi nonparametrik sehingga model MARS tidak bergantung pada asumsi tertentu. Metode MARS berguna untuk mengatasi permasalahan data yang berdimensi tinggi. Dalam metode MARS, Generalized Cross Validation (GCV) adalah kriteria yang paling baik untuk seleksi model tebaik.

Data yang digunakan pada penelitian ini adalah data Produk Domestik Regional Bruto Jawa Tengah selama 11 tahun. Jumlah pengamatan yang digunakan dalam penelitian ini relatif kecil. Oleh karena itu dalam penelitian ini, metode MARS akan dikombinasikan dengan metode resampling dalam penyusunannya. Metode resampling yang digunakan adalah Bootstrap Aggregating (Bagging). Dengan menggunakan metode Bootstrap Aggregating Multivariate Adaptive Regression Splines diharapkan dapat memperbaiki stabilitas, meningkatkan akurasi dan kekuatan prediktif.

\section{TINJAUAN PUSTAKA}

\subsection{Produk Domestik Regional Bruto (PDRB)}

PDRB adalah jumlah nilai tambah yang dihasilkan oleh seluruh aktivitas produksi di dalam perekonomian daerah (BPS, 2013). Hal ini berarti peningkatan PDRB mencerminkan pula peningkatan balas jasa kepada faktor produksi yang digunakan dalam aktivitas produksi tersebut.

Berdasarkan Buku Profil Produk Domestik Regional Bruto Menurut Lapangan Usaha 2013-2017, PDRB dibedakan menjadi dua, yakni PDRB atas dasar harga berlaku dan PDRB atas dasar harga konstan. PDRB harga berlaku (nominal) menunjukkan kemampuan sumber daya ekonomi yang dihasilkan suatu wilayah. Nilai PDRB yang besar menunjukkan kemampuan sumber daya ekonomi yang besar, begitu juga sebaliknya. PDRB konstan (riil) dapat digunakan untuk menunjukkan pertumbuhan ekonomi secara keseluruhan atau setiap kategori dari tahun ke tahun. Penyajian PDRB ini dinilai seluruhnya dengan harga tahun dasar (tahun 2010). Karena setiap tahun dinilai atas dasar harga tetap yang terjadi pada tahun dasar, maka perkembangan PDRB dari tahun ke tahun merupakan perkembangan riil dan bukan disebabkan oleh kenaikan harga. PDRB yang digunakan adalah nilai PDRB atas dasar harga konstan.

\subsection{Pendapatan Asli Daerah}

Menurut Pasal 1 Undang-Undang No. 33 Tahun 2004 tentang Perimbangan Keuangan antara Pemerintah Pusat dan Pemerintahan Daerah, Pendapatan Asli Daerah 
(PAD) adalah penerimaan yang diperoleh daerah dari sumber-sumber di dalam daerahnya sendiri yang dipungut berdasarkan peraturan daerah sesuai dengan peraturan perundangundangan yang berlaku. Pendapatan Asli Daerah merupakan sumber penerimaan daerah yang asli digali di daerah yang digunakan untuk modal dasar pemerintah daerah dalam membiayai pembangunan dan usaha-usaha daerah untuk memperkecil ketergantungan dana dari pemerintah pusat (Kuncoro, 2004).

Berdasarkan Pasal 157 Undang-Undang No. 32 Tahun 2004, sumber pendapatan daerah adalah Pendapatan Asli Daerah (PAD) yang terdiri dari hasil pajak daerah, hasil retribusi daerah, hasil pengelolaan kekayaan daerah yang dipisahkan dan lain-lain PAD yang sah.

\subsection{Investasi}

Investasi merupakan suatu cara yang dapat dilakukan oleh pemerintah untuk meningkatkan pertumbuhan ekonomi dan untuk jangka panjang dapat menaikan standar hidup masyarkatnya (Mankiw, 2003). Teori ekonomi mendefinisikan investasi sebagai pengeluaran-pengeluaran untuk membeli barang-barang modal dan peralatan produksi dengan tujuan untuk mengganti dan terutama menambah barang-barang modal dalam perekonomian yang akan digunakan untuk memproduksi barang dan jasa (Sukirno, 2000).

\subsubsection{Penanaman Modal Asing (PMA)}

Menurut UU No. 1 Tahun 1967 tentang PMA, yang dimaksud dengan Penanaman Modal Asing (PMA) adalah penanaman modal asing secara langsung yang dilakukan menurut atau berdasarkan ketentuan-ketentuan Undang-undang ini dan yang digunakan untuk menjalankan Perusahaan di Indonesia, dalam arti bahwa pemilik modal secara langsung menanggung resiko dari penanaman modal tersebut.

\subsubsection{Penanaman Modal Dalam Negeri (PMDN)}

Dalam Undang-Undang No. 6 Tahun 1968 tentang Penanaman Modal Dalam Negeri (PMDN), disebutkan terlebih dulu definisi modal dalam negeri pada pasal 1, Undang-undang ini menjelaskan bahwa "modal dalam negeri" adalah bagian dari kekayaan masyarakat Indonesia termasuk hak-hak dan benda-benda, baik yang dimiliki Negara maupun swasta asing yang berdomosili di Indonesia yang disisihkan atau disediakan guna menjalankan suatu usaha sepanjang.

\subsection{Statistik deskriptif}

Statistik deskriptif merupakan tahapan analisis yang berkaitan dengan pengumpulan dan penyajian data sehingga menghasilkan informasi yang bermanfaat. Bentuk penyajian statistik deskriptif dapat berupa tabel, grafik, diagram, histogram, dan lainnya (Walpole, 1993).

\subsection{Analisis regresi}

Analisis regresi merupakan salah satu analisis dalam statistika yang sangat banyak digunakan untuk melihat hubungan dan pengaruh variabel-variabel prediktor terhadap responnya. Analisis regresi adalah suatu analisis statistik yang memanfaatkan hubungan antara dua variabel atau lebih (Montgomery and Peck, 1992).

\subsection{Regresi nonparametrik}

Menurut Eubank (1999) Regresi nonparametrik merupakan metode pendekatan regresi yang sesuai untuk pola data dan tidak diketahui kurva regresi atau tidak terdapat 
informasi lengkap masa lalu tentang pola data. Secara umum model regresi nonparametrik dapat dituliskan sebagai berikut:

$$
y_{i}=f\left(x_{i}\right)+\varepsilon_{i}
$$

\subsection{Multivariate Adaptive Regression Splines (MARS)}

Multivariate Adaptive Regression Splines (MARS) merupakan metode dengan pendekatan regresi nonparametrik yang pertama kali diperkenalkan oleh Friedman pada tahun 1991. Menurut Friedman (1991) Model MARS berguna untuk mengatasi permasalahan data berdimensi tinggi. Data berdimensi tinggi yang dimaksud adalah data dengan ukuran $3 \leq \mathrm{p} \leq 20$, dimana $\mathrm{p}$ adalah banyak variabel prediktor dan sampel data yang berukuran $50 \leq \mathrm{n} \leq 1000$, dimana $\mathrm{n}$ untuk ukuran sampel.

Model umum persamaan MARS dapat ditulis sebagai berikut:

dengan,

$$
f(x)=\alpha_{0}+\sum_{m=1}^{M} \alpha_{m} \prod_{k=1}^{K_{m}}\left[s_{k m}\left(x_{v(k, m)}-t_{k m}\right)\right]_{+}
$$

$\alpha_{0} \quad=$ konstanta regresi dari fungsi basis

$\alpha_{\mathrm{m}}=$ koefisien dari fungsi basis ke- $m$

$\mathrm{M}=$ maksimum fungsi basis (nonconstant fungsi basis)

$K_{m}=$ derajat interaksi

$S_{k m}=$ bernilai +1 jika knot terletak di kanan titik knot, dan bernilai -1 jika knot terletak di kiri titik knot

$x_{v(k, m)}=$ variabel prediktor ke-v, pilahan ke-k dan subregion ke-m

$t_{k m}=$ nilai $k n o t$ dari variabel prediktor $\mathrm{x}_{\mathrm{v}(\mathrm{k}, \mathrm{m})}$

Menurut Nash dan Bradford (2001) ada dua hal yang perlu diperhatikan dalam menggunakan model MARS yaitu knot dan basis fungsi.

1. Knot, Ketika satu garis regresi tidak fit untuk suatu data yang bersifat piecewise, maka beberapa garis regresi dapat digunakan untuk menyatakan pola suatu data. Nilai variabel prediktor ketika slope suatu garis regresi mengalami perubahan disebut dengan knot. Setiap garyregresi mendefinisikan satu region sehingga knot dapat didefinisikan sebagai akhir dari satu region dan awal dari region yang lain. Minimum jarak antara knot atau minimum observasi antara knot (MO) ditentukan dengan cara trial dan error sampai diperoleh GCV minimum.

2. Basis Function / (Fungsi Basis) yaitu kumpulan dari fungsi yang digunakan untuk mewakili informasi. Basis fungsi terdiri dari satu atau lebih variabel. Basis fungsi merupakan suatu fungsi yang digunakan untuk menjelaskan hubungan antara variabel respon dan variabel prediktor Basis fungsi ini merupakan fungsi parametrik yang didefinisikan pada tiap region.

\section{8. $\quad$ Booststrap Aggregating (Bagging)}

Bagging merupakan suatu metode yang pertama kali dikenalkan oleh Breiman (1994). Metode ini digunakan sebagai alat untuk memperbaiki stabilitas dan kekuatan prediksi dengan cara mereduksi variansi dari suatu prediktor. Banyak versi yang dibentuk dengan replikasi booststrap berasal dari sebuah himpunan data. Pada beberapa kasus bagging pada himpunan data asli atau simulasi dapat meningkatkan akurasi. Jika perubahan dalam himpunan data menyebabkan perubahan yang signifikan maka bagging dapat meningkatkan akurasi. Ide dasar bagging adalah menggunakan resampling boostrap untuk membangkitkan prediktor dengan banyak versi, dimana ketika dikombinasikan 
seharusnya hasilnya lebih baik dibandingkan dengan prediktor tunggal yang dibangun untuk menyelesaikan masalah yang sama.

Berikut ini merupakan algoritma bagging menurut Buhlmann dan Yu (2002):

1. Sebuah himpunan data yang terdiri dari $\left\{\left(\mathrm{y}_{\mathrm{i}}, \mathrm{x}_{\mathrm{i}}\right), \mathrm{i}=1, \ldots, \mathrm{n}\right\}$. Melakukan replikasi bootsrap pada data tersebut sehingga didapatkan

$\mathrm{L}_{i^{\star}}=\left(\mathrm{y}_{i}^{*}, \mathrm{x}_{i}^{*}\right), \mathrm{i}=1,2, \ldots, \mathrm{n}$

2. Replikasi bootsrap dilakukan sebanyak B kali, sehingga didapatkan, sehingga didapatkan $\mathrm{L}^{(\mathrm{B})}$ dari L. $\mathrm{L}^{(\mathrm{B})}$ adalah resampling dengan pengembalian.

\section{METODE PENELITIAN}

\subsection{Sumber Data dan Variabel Penelitian}

Data yang digunakan dalam penelitian ini merupakan data sekunder yang diambil dari publikasi BPS Jawa Tengah dalam bukunya Jawa Tengah dalam Angka. Objek dari penelitian ini adalah nilai dari Produk Domestik Regional Bruto (PDRB) atas dasar harga konstan di Jawa Tengah dalam kurun waktu 11 tahun. Sedangkan variabel prediktornya adalah Pendapatan Asli Daerah $\left(\mathrm{X}_{1}\right)$, Penanaman Modal Asing $\left(\mathrm{X}_{2}\right)$ dan Penanaman Modal Dalam Negeri $\left(\mathrm{X}_{3}\right)$.

\subsection{Tahapan Analisis Data}

1. Mengumpulkan data variabel respon dan prediktor.

2. Analisis deskriptif variabel respon dan variabel prediktor.

3. Melakukan analisis MARS dengan bantuan software Salford Predictive Modeler (SPM) 7.0. Langkah - langkah analisisnya adalah

a. Pembentukan model MARS terbaik untuk data Produk Domestik Regional Bruto (PDRB) dengan mengkombinasikan besarnya Basis Function (BF), Maximum Interaction (MI), dan Minimum Observation (MO). Dilakukan dengan cara trial and error dengan menentukan nilai maksimum BF, yaitu 2 sampai 4 kali banyaknya variabel prediktor yang digunakan, menentukan nilai MI yaitu 1, 2 dan 3 dengan pertimbangan jika MI > 3 akan menghasilkan model yang semakin kompleks, dan menentukan minimal banyaknya pengamatan setiap knot (MO) yaitu 0,1,2 dan 3 .

b. Menentukan model MARS terbaik berdasarkan nilai GCV terkecil yang diperoleh dari kombinasi BF, MI dan MO.

c. Melakukan interpretasi model MARS terbaik dan interpretasi variabel variabel yang berpengaruh dalam model tersebut.

4. Melakukan bagging pada himpunan data awal dengan 10, 25, 35, 40, 55, 75, 85, 90 dan 100 replikasi bootstrap.

5. Melakukan pemodelan MARS pada setiap pengambilan sampel B replikasi bootstrap.

6. Mendapatkan nilai GCV pada setiap pengambilan sampel sampai B replikasi.

7. Mendapatkan nilai GCV bagging dari rata-rata GCV pada setiap pengambilan sampel sampai B replikasi.

8. Melakukan interpretasi GCV bagging MARS yang diperoleh.

\section{HASIL DAN PEMBAHASAN}

4.1. Statistika Deskriptif

\subsubsection{Produk Domestik Regional Bruto (PDRB)}

Statistik deskriptif variabel Produk Domestik Regional Bruto (PDRB) dapat dilihat pada Tabel 1. Berdasarkan Tabel 1, nilai maximum, minimum dan mean dari variabel 
Produk Domestik Regional Bruto (PDRB) dengan banyaknya data sebesar 11 buah yaitu 806,765 dan 476,772 dengan rata-rata sebesar 629,760

Tabel 1. Statistik Deskriptif Produk Domestik Regional Bruto (PDRB)

\begin{tabular}{|c|c|c|c|c|}
\hline & N & MAX & MIN & Mean \\
\hline PDRB & 11 & 806,7651 & 476,7721 & 629,7598 \\
\hline
\end{tabular}

\subsubsection{Pendapatan Asli Daerah (PAD)}

Pendapatan Asli Daerah merupakan salah satu faktor Produk Domestik Regional Bruto (PDRB).

Tabel 2. Pendapatan Asli Daerah (PAD)

\begin{tabular}{|c|c|c|c|c|}
\hline & $\mathrm{N}$ & MAX & MIN & Mean \\
\hline PAD & 11 & 10,90488 & 0,0025 & 3,0482 \\
\hline
\end{tabular}

Pendapatan Asli Daerah merupakan salah satu faktor Produk Domestik Regional Bruto (PDRB). Berdasarkan Tabel 2, nilai maximum, minimum dan mean dari variabel Pendapatan Asli Daerah (PAD) dengan banyaknya data sebesar 11 buah yaitu 10,905 dan 0,0025 dengan rata-rata sebesar 3,048.

\subsubsection{Penanaman Modal Asing (PMA)}

Penanaman Modal Asing (PMA) merupakan salah satu faktor Produk Domestik Regional Bruto (PDRB).

Tabel 3. Penanaman Modal Asing

\begin{tabular}{|c|c|c|c|c|}
\hline & N & MAX & MIN & Mean \\
\hline PMA & 11 & 0,7938 & 0,0002 & 0,0741 \\
\hline
\end{tabular}

Berdasarkan Tabel 3, nilai maximum, minimum dan mean dari variabel Penanaman Modal Dalam Negeri dengan banyaknya data sebesar 11 buah yaitu 0,7938 dan 0,0002 dengan rata-rata sebesar 0,0741 .

\subsubsection{Penanaman Modal Dalam Negeri (PMDN)}

Penanaman Modal Dalam Negeri (PMDN) merupakan salah satu faktor Produk Domestik Regional Bruto (PDRB). Berdasarkan Tabel 4, nilai maximum, minimum dan mean dari variabel Penanaman Modal Dalam Negeri dengan banyaknya data sebesar 11 buah yaitu 7,370 dan 0,776 dengan rata-rata sebesar 2,957.

Tabel 4. Penanaman Modal Dalam Negeri

\begin{tabular}{|c|c|c|c|c|}
\hline & N & MAX & MIN & Mean \\
\hline PMDN & 11 & 7,3697 & 0,7758 & 2,9572 \\
\hline
\end{tabular}

\section{2. $\quad$ Pemodelan Multivariate Adaptive Regression Splines}

Dalam melakukan pemodelan Produk Domestik Regional Bruto di Jawa Tengah berdasarkan trial and error dalam mengkombinasikan jumlah fungsi basis (BF), maksimum interaksi (MI), dan minimum observasi (MO). Nilai dari BF sebesar 6, 9, dan 12. Nilai dari MI sebesar 1, 2, dan 3. Sedangkan nilai dari MO sebesar 0, 1, 2, dan 3. 
Banyaknya model yang mungkin berdasarkan kombinasi tersebut adalah sebanyak 36 model. Dari masing-masing percobaan ini akan dihasilkan nilai GCV dan diperoleh variabel prediktor yang masuk dalam model. Penentuan model MARS terbaik berdasarkan nilai GCV minimum.

Berdasarkan Tabel 5, model terbaik yang diperoleh dari hasil kombinasi terkecil yaitu $\mathrm{BF}=6, \mathrm{MI}=1$ dan $\mathrm{MO}=0$ yaitu dengan $\mathrm{GCV}$ minimum sebesar 5.667,6680. Sehingga di dapatkan model terbaik dalam MARS untuk memodelkan faktor-faktor yang mempengaruhi Produk Domestik Regional Bruto di Provinsi Jawa Tengah yang dapat dituliskan dengan persamaan sebagai berikut:

$$
\mathrm{Y}=562,093+22,2174 * B F_{1}
$$

dengan:

$B F_{1}=\max (0, P A D-0,002491)$

Tabel 5. Penentuan Model Terbaik

\begin{tabular}{|c|c|c|c|c|c|}
\hline NO & $\mathrm{BF}$ & MI & $\mathrm{MO}$ & GCV & $R^{2}$ \\
\hline $1 *$ & 6 & 1 & 0 & $5.667,6680$ & 0,7890 \\
\hline $2 *$ & 6 & 1 & 1 & $5.667,6680$ & 0,7890 \\
\hline $3^{*}$ & 6 & 1 & 2 & $5.667,6680$ & 0,7890 \\
\hline $4^{*}$ & 6 & 1 & 3 & $5.667,6680$ & 0,7890 \\
\hline 5 & 6 & 2 & 0 & $7.714,3238$ & 0,7890 \\
\hline 6 & 6 & 2 & 1 & $7.714,3238$ & 0,7890 \\
\hline 7 & 6 & 2 & 2 & $7.714,3238$ & 0,7890 \\
\hline 8 & 6 & 2 & 3 & $7.714,3238$ & 0,7890 \\
\hline 9 & 6 & 3 & 0 & $7.714,3238$ & 0,7890 \\
\hline 10 & 6 & 3 & 1 & $7.714,3238$ & 0,7890 \\
\hline 11 & 6 & 3 & 2 & $7.714,3238$ & 0,7890 \\
\hline 12 & 6 & 3 & 3 & $7.714,3238$ & 0,7890 \\
\hline $13 *$ & 9 & 1 & 0 & $5.667,6680$ & 0,7890 \\
\hline $14^{*}$ & 9 & 1 & 1 & $5.667,6680$ & 0,7890 \\
\hline $15 *$ & 9 & 1 & 2 & $5.667,6680$ & 0,7890 \\
\hline $16^{*}$ & 9 & 1 & 3 & $5.667,6680$ & 0,7890 \\
\hline 17 & 9 & 2 & 0 & $7.714,3238$ & 0,7890 \\
\hline 18 & 9 & 2 & 1 & $7.714,3238$ & 0,7890 \\
\hline 19 & 9 & 2 & 2 & $7.714,3238$ & 0,7890 \\
\hline 20 & 9 & 2 & 3 & $7.714,3238$ & 0,7890 \\
\hline 21 & 9 & 3 & 0 & $7.714,3238$ & 0,7890 \\
\hline 22 & 9 & 3 & 1 & $7.714,3238$ & 0,7890 \\
\hline 23 & 9 & 3 & 2 & $7.714,3238$ & 0,7890 \\
\hline 24 & 9 & 3 & 3 & $7.714,3238$ & 0,7890 \\
\hline $25^{*}$ & 12 & 1 & 0 & $5.667,6680$ & 0,7890 \\
\hline $26^{*}$ & 12 & 1 & 1 & $5.667,6680$ & 0,7890 \\
\hline
\end{tabular}




\begin{tabular}{|c|c|c|c|c|c|}
\hline $27 *$ & 12 & 1 & 2 & $5.667,6680$ & 0,7890 \\
\hline $28 *$ & 12 & 1 & 3 & $5.667,6680$ & 0,7890 \\
\hline 29 & 12 & 2 & 0 & $7.714,3238$ & 0,7890 \\
\hline 30 & 12 & 2 & 1 & $7.714,3238$ & 0,7890 \\
\hline 31 & 12 & 2 & 2 & $7.714,3238$ & 0,7890 \\
\hline 32 & 12 & 2 & 3 & $7.714,3238$ & 0,7890 \\
\hline 33 & 12 & 3 & 0 & $7.714,3238$ & 0,7890 \\
\hline 34 & 12 & 3 & 1 & $7.714,3238$ & 0,7890 \\
\hline 35 & 12 & 3 & 2 & $7.714,3238$ & 0,7890 \\
\hline 36 & 12 & 3 & 3 & $7.714,3238$ & 0,7890 \\
\hline
\end{tabular}

$*=$ Nilai GCV terendah

\subsection{Interpretasi Model MARS}

Model MARS pada persamaan (3) selain menggambarkan hubungan antara variabel prediktor dan variabel respon juga kontribusi setiap fungsi basis (BF) terhadap model MARS pada persamaan (3) yang dapat dijelaskan sebagai berikut :

1. $B F_{1}$

$B F_{1}=\max (0, P A D-0,002491)$

$\{(P A D-0,002491)$ jika $P A D>0,002491$

dengan koefisien sebesar 22,2174

Artinya setiap kenaikan $B F_{1}$ sebesar satu triliun akan menambah nilai Produk Domestik Regional Bruto di Jawa Tengah sebesar 22,2174 dengan Pendapatan Asli Daerah lebih besar dari 0,002491.

\subsection{Tingkat Kepentingan Variabel}

Berdasarkan Tabel 6, diperoleh informasi bahwa variabel Pendapatan Asli Daerah yang mempunyai pengaruh dominan terhadap Produk Domestik Bruto Regional sebesar 100\%. Selain itu, variabel Penanaman Modal Asing dan Penanaman Modal Dalam Negeri tidak memiliki pengaruh terhadap Produk Domestik Bruto Regional.

Tabel 6. Tingkat Kepentingan Variabel

\begin{tabular}{|c|c|}
\hline Variabel & Importance \\
\hline PAD & 100 \\
\hline PMDN & 0 \\
\hline PMA & 0 \\
\hline
\end{tabular}

\subsection{Bootstrap Aggregating Multivariate Adaptive Regression Splines (Bagging MARS)}

Berdasarkan dari Tabel 7, pada replikasi 55 diperoleh nilai minimum GCV di antara replikasi lainnya yaitu sebesar 2.258,6192. Nilai GCV pada Bagging MARS tersebut lebih kecil dibandingkan nilai GCV pada model MARS. Dengan diperolehnya nilai GCV pada Bagging MARS yang lebih kecil dibandingkan dengan GCV model 
MARS, menunjukkan bahwa bagging dapat menurunkan nilai GCV dan meningkatkan akurasi, sehingga metode ini dapat digunakan dalam penelitian ini. 
Tabel 7. Hasil Bagging MARS

\begin{tabular}{|c|c|l|}
\hline Replikasi & GCV & $R^{2}$ \\
\hline 10 & $2.371,8466$ & 0,7363 \\
\hline 25 & $2.491,4109$ & 0,6409 \\
\hline 35 & $2.431,3089$ & 0,6362 \\
\hline 40 & $2.309,9994$ & 0,6378 \\
\hline $55^{*}$ & $2.258,6192$ & 0,6290 \\
\hline 75 & $2.303,2798$ & 0,6372 \\
\hline 85 & $2.296,5937$ & 0,6174 \\
\hline 90 & $2.353,3055$ & 0,6265 \\
\hline 100 & $2.380,4869$ & 0,6309 \\
\hline
\end{tabular}

Estimasi parameter model bagging merupakan nilai rata-rata estimasi parameter B kali replikasi bootstrap. Namun, karena nilai knots yang berubah-ubah dalam pembentukan model Bagging MARS di setiap replikasi bootstrap sehingga untuk menduga estimasi parameternya tidak dapat dihitung. Dari 55 model Bagging MARS terdapat model terbaik pada replikasi ke-3 dengan nilai GCV minimum sebesar 0,736703 dengan model:

$\mathrm{Y}=588,87966-35,07091 * B F_{1}-40,45791 * B F_{2}+61687,32338 * B F_{3}$

\section{KESIMPULAN}

Kesimpulan yang dapat diambil dari hasil dan pembahasan adalah sebagai berikut:

1. Model Multivariate Adaptive Regression Splines (MARS) terbaik untuk Produk Regional Bruto Provinsi Jawa Tengah adalah kombinasi $\mathrm{BF}=6, \mathrm{MI}=1, \mathrm{MO}=0$ dan GCV sebesar 5.667,6680. Dengan persamaan model sebagai berikut :

dimana :

$$
\mathrm{Y}=562,093+22,2174 * B F_{1}
$$

$B F_{1}=\max (0, P A D-0,002491)$

2. Besar tingkat pentingnya variabel-variabel prediktor terhadap model terbaik yang diperoleh mempengaruhi Produk Domestik Regional Bruto adalah Pendapatan Asli Daerah dengan tingkat pentingnya sebesar $100 \%$

3. Hasil pemodelan dari Bagging MARS menunjukkan bawah nilai GCV yang di peroleh sebesar 2.258,6192 lebih kecil dari GCV model MARS terbaik sebesar 5.667,6680. Dengan menggunakan bagging memberikan hasil yang lebih baik dibandingkan dengan metode MARS. Hal ini menunjukkan bahwa bagging MARS dalam penelitian ini dapat meminimumkan nilai GCV dan meningkatkan akurasi.

4. Metode Bagging MARS dengan 55 replikasi lebih tepat digunakan untuk Produk Domestik Regional Bruto di Jawa Tengah.

\section{DAFTAR PUSTAKA}

Arsyad, L. 1999. Pengantar Perencanaan dan Pembangunan Ekonomi Daerah. BPFE, Yogyakarta.

Badan Pusat Statistik [BPS]. 2013. Produk Domestik Regional Bruto Jawa Tengah 2013. Semarang: Badan Pusat Statistik Jawa Tengah 
Breiman, L. 1994. Bagging Predictor. Technical report No. 421. Departement of Statistics University of California.

Buhlmann, P. and Yu, B. 2002. Analyzing Bagging, The Annals of Statistic. New York . Vol. 30 No. 4, hal 927-961.

Eubank, R.L. 1999. Nonparametric Regression and Spline Smoothing. New York: Marcel Deker.

Friedman, J. H. 1991. Multivariate Adaptive Regression Splines. The Annals of Statistics, Vol. 19 No. 1.

Kuncoro, M. 2004. Otonomi dan Pembangunan Daerah. Yogyakarta: Unit Percetakan dan percetakan STIM YKPN Yogyakarta.

Mankiw, N. G. 2003. Teori Makroekonomi Edisi Kelima. Terjemahan. Jakarta: Penerbit Erlangga.

Montgomery, D.C. and Peck, E.A. 1992. Introduction to Linear Regression Analysis, 2nd Edition. John Wiley \& Sons, New York.

Nash, M. S. and Bradford, D. F. 2001. Parametric and Non Parametric Logistic Regression for Prediction of Precense/ Absence of an Amphibian. [online]. Tersedia: http://www.epa.gov/esd/land-sci/pdf/0081eb02.pdf.

Republik Indonesia. 1967. Undang-Undang No. 1 Tahun 1967 tentang Penanaman Modal Asing. Jakarta.

Republik Indonesia. 1968. Undang-Undang No. 6 Tahun 1968 tentang Penanaman Modal Dalam Negeri. Jakarta.

Republik Indonesia. 2004. Undang-Undang No. 33 Tahun 2004 tentang Perimbangan Keuangan Antara Pemerintah Pusat dan Pemerintahan Daerah. Jakarta.

Republik Indonesia. 2004. Undang-Undang No. 32 Tahun 2004 tentang Pemerintahan Daerah. Jakarta.

Saragih, J. P. 2003. “Desentralisasi Fiskal Keuangan Daerah Dalam Otonomi”. Jakarta: Ghalia Indonesia.

Sukirno, S. 2000. Makroekonomi Modern. Jakarta: PT Raja Drafindo Persada.

Walpole, R.E. 1993. Pengantar Statistika Edisi ke-3. Jakarta: PT. Gramedia Pustaka Utama. 